\title{
Permainan Karpet Engkle: Aktivitas Motorik untuk Meningkatkan Keseimbangan Tubuh Anak Usia Dini
}

\author{
Ruqoyyah Fitri', Meidita Lissofi Imansari ${ }^{2}$ \\ Pendidikan Guru Pendidikan Anak Usia Dini, Universitas Negeri Surabaya \\ DOI: $\underline{10.31004 / \text { obsesi.v5i2.754 }}$
}

\begin{abstract}
Abstrak
Tujuan penelitian ini adalah melakukan preliminary research dengan cara menguji validitas dan reliabilitas instrument motorik kasar dan perangkat permainan karpet engkle agar layak digunakan dalam mengukur keseimbangan statis dan keseimbangan dinamis. Metode penelitian menggunakan kuantitatif deskriptif dengan subjek uji coba terdiri dari satu orang anak usia 4-5 tahun yang diamati kinerja motoriknya oleh dua orang rater, serta dua orang ahli meliputi ahli materi dan ahli desain. Analisis data pendahuluan diperoleh dari hasil uji validitas menggunakan teknik peer review oleh ahli dan uji reliabilitas menggunakan inter-rater reliability dengan rumus cohen kappa. Hasil uji validitas terhadap instrumen kemampuan keseimbangan diperoleh nilai 91,45\%, lembar RPPH dengan nilai 86\%, alat permainan karpet engkle sebesar $91,42 \%$, dan buku panduan permainan 85,45\%. Hasil uji reliabilitas diperoleh nilai sebesar 0,75 menunjukkan kesepakatan kuat. Berdasarkan hasil analisis data uji validitas dan reliabilitas dapat disimpulkan bahwa permainan karpet engkle layak digunakan untuk anak usia 4-5 tahun dan reliabel untuk mengukur kemampuan keseimbangan statis dan dinamis sehingga dapat diterapkan dalam penelitian lanjutan berupa penelitian eksperimen.

Kata Kunci: penelitian pendahuluan, kemampuan keseimbangan, permainan karpet engkle.
\end{abstract}

\begin{abstract}
The purpose of this study was to conduct preliminary research by testing the validity and reliability of the gross motor instrument and the karpet engkle game device so that it is suitable for use in measuring the static balance and dynamic balance. The research method used descriptive quantitative with the trial subjects consisting of one 4-5 year old child whose motor performance was observed by two raters, as well as two experts including experts materials and design experts. Preliminary data analysis was obtained from the results of validity testing using peer review techniques by expert judgment and reliability testing using inter-rater reliability with the cohen kappa formula. The results of the validity test of the balance ability instrument obtained a value of $91.45 \%$, RPPH sheet with a value of $86 \%$, a karpet engkle game tool of $91.42 \%$, and a game guide book of $85.45 \%$. The reliability test results obtained a value of 0.75 indicating a strong agreement. Based on the results of the analysis of the validity and reliability test data, it can be concluded that the karpet engkle game is suitable for children aged 4-5 years and reliable to measure the balance and dynamic ability so that it can be applied in further research in the form of experimental research.
\end{abstract}

Keywords: preliminary research, balance ability, karpet engkle game.

Copyright (c) 2020 Ruqoyyah Fitri, Meidita Lissofi Imansari

$\triangle$ Corresponding author:

Email Address : ruqoyyahfitri@unesa.ac.id (Jl. Lidah Wetan, Surabaya)

Received 8 September 2020, Accepted 10 October 2020, Published 22 October 2020 


\section{PENDAHULUAN}

Anak usia dini memiliki karakteristik bersifat unik. Perbedaan pada setiap individual menjadikan setiap anak memiliki keunikan masing-masing dengan kemampuan yang berbeda-beda. Ciri khusus anak usia dini yaitu selalu tumbuh dan berkembang sejak dalam kandungan. Pertumbuhan dan perkembangan anak terjadi secara teratur sesuai dengan tahapan-usia, dari dalam kandungan hingga anak terlahir dan saling berkesinambungan satu sama lain (Adhe et al., 2018). Apabila salah satu tahapan terlewati dan aspek perkembangan tidak berkembang optimal maka akan mempengaruhi tumbuh kembang anak. Aspek perkembangan yang penting peranannya dalam kehidupan anak adalah aspek fisik motorik.

Perkembangan fisik motorik adalah pengendalian gerak jasmani melalui kegiatan yang berhubungan dengan urat saraf, pusat saraf, dan otot yang dapat dikoordinir. Aspek perkembangan fisik motorik merupakan hal mendasar bagi kemajuan perkembangan aspekaspek yang lainnya. Perkembangan ini berkembang seiring dengan kematangan otot dan syaraf pada tubuhnya, ditandai dengan penguasaan keterampilan motorik. Keterampilan motorik kasar adalah gerakan yang melibatkan otot besar. Keterampilan motorik kasar memerlukan beberapa unsur, diantaranya: kecepatan, kekuatan, ketahanan, kelincahan, fleksibilitas, koordinasi, dan keseimbangan (Erlinda, dkk., 2014).

Keterampilan keseimbangan diartikan sebagai keterampilan mempertahankan tubuh ketika berada di berbagai posisi. Keseimbangan dalam bidang sains dikenal dengan sistem vestibularis. Reseptor vestibular dalam tubuh yang bertugas sebagai pengatur keseimbangan diatur oleh organ apparatus vestibularis atau labirin. Labirin merupakan bagian telinga dalam, tetapi sering diartikan sebagai alat vestibular.

Beberapa faktor yang berpengaruh pada keseimbangan tubuh, yaitu: (1) Center of Gravity (COG), yakni kemampuan seseorang untuk mempertahankan keseimbangan dengan menyangga dari gaya gravitasi dalam berbagai bentuk posisi; (2) Line of Gravity (LOG), garis khayal yang vertikal melalui pusat gravitasi dengan pusat bumi; (3) Bidang tumpu (Base of Support-BOS), merupakan dasar tempat bertumpu atau berpijak tubuh (Susanti dan Irfan, 2010). Hubungan dari ketiga faktor tersebut adalah menentukan derajat stabilitas keseimbangan tubuh kita.

Mobilitas yang tinggi pada anak usia dini membuat anak aktif bergerak. Mereka menyukai gerakan sederhana seperti meloncat, melompat, melempar, menendang dan berlari. Menurut hasil penelitian (Astutik \& Fitri, 2019) pada dasarnya anak-anak menyukai olahraga dan berbagai aktivitas fisik, tidak berdiri diam dan ingin terus bergerak. Namun, beberapa anak mengalami masalah perkembangan motorik yang tidak sesuai dengan pertambahan usianya. Tidak semua anak mendapatkan stimulasi keseimbangan tubuh yang optimal, dan hal ini mempengaruhi oleh perkembangan motoriknya.

Dalam perkembangan motorik kasar anak usia dini secara keseluruhan, ada dua hal yang menjadi kendala, yaitu ketidakmampuan untuk mengatur keseimbangan, respon yang kurang cepat dan koordinasi yang buruk. Sekitar $80 \%$ dari anak yang mempunyai masalah pada perkembangan kesulitan untuk mengatur keseimbangan dan mengontrol gerakan anggota tubuh sehingga anak terlihat ragu-ragu pada saat melakukan gerakan (Wiyani, 2014). Ketidakmampuan mencapai keseimbangan yang optimal dapat mengakibatkan terganggunya aktivitas fungsional sehari-hari yang membuat anak lebih mudah terjatuh dan cedera, sulit menstabilkan tubuh saat bagian tubuh lain bergerak, sulit mempertahankan postur tubuh saat duduk, berdiri, berjalan dan berlari, dan kesulitan melakukan beragam gerakan lainnya.

Berdasarkan hasil pengamatan di TK Sekolah Alam Insan Mulia Surabaya yang dilaksanakan pada bulan Agustus 2019 ditemukan bahwa, anak mengalami masalah pada motorik kasar berterkaitan dengan ketidakmampuan anak mengatur keseimbangan tubuhnya. Yang pertama dilihat ketika anak berjalan, beberapa anak pada saat berjalan masih sempoyongan, belum bisa mengatur keseimbangan tubuhnya saat berjalan. Selanjutnya yang kedua dilihat dari kemampuan anak pada saat bermain papan titian. Anak belum mampu 
berjalan di atas papan titian karena kesulitan untuk menyeimbangkan tubuhnya, anak merasa ragu-ragu saat bermain, dan mudah terjatuh saat berjalan diatas papan titian, sehingga perlu bantuan guru dan temannya pada saat bermain. Anak sulit dalam mengontrol gerakan tubuh seperti (kepala, bahu, tangan dan kaki).

Hambatan perkembangan motorik ini disebabkan oleh kemampuan keseimbangan yang buruk, menyebabkan kesulitan melakukan aktivitas fungsional sehari-hari (Schwam \& Wanna, 2019). Anak kesulitan menyangga tubuh dari gaya gravitasi (center of gravity), kurangnya kemampuan menjaga keseimbangan antara pusat massa tubuh dan bidang tumpu, serta kurangnya kemampuan menstabilkan bagian tubuh ketika bagian tubuh lain sedang bergerak. Jika tidak segera ditangani, maka akan berdampak besar bagi proses tumbuh kembangan anak tersebut. Akibat dari semua itu adalah anak memilih mengasingkan diri dari lingkungannya (Fajar, dkk., 2013).

Oleh karena itu diperlukan suatu metode yang tepat untuk mengatasi masalah gangguan keseimbangan, salah satunya dengan balance exercise atau latihan keseimbangan. Dengan latihan keseimbangan akan membuat otot-otot bagian bawah anak kuat dan anak dapat menompang beban tubuhnya pada titik tumpu secara seimbang. Latihan fisik motorik juga dapat meningkatkan kinerja otak (Fitri, 2017). Ketika melakukan latihan keseimbangan harus memperhatikan faktor-faktor yang mempengaruhinya, antara lain: pusat gravitasi tubuh, ketinggian dari pusat tubuh ketitik tumpu dan luas titik tumpu (Rindang \& Ungaran, 2014)

Kegiatan balance exercise di sekolah salah satunya dapat dilakukan melalui olahraga dan permainan. Penelitian ini menggunakan permainan karpet engkle sebagai media untuk melatih gerakan motorik kasar khususnya keseimbangan statis dan dinamis, memacu penggunaan otot-otot besar anak, mengontrol gerak tubuh, mengkoordinasikan dan meningkatkan keterampilan fisik, untuk mendukung pertumbuhan tubuh yang sehat, kuat, dan terampil. Permainan karpet engkle adalah permainan modifikasi dari permainan tradisional engkle. Tujuan utama dari memodifikasi permainan adalah untuk membuat permainan lebih menyenangkan dan menarik bagi anak, sehingga pada proses pembelajaran permainan karpet engkle ini dapat memberikan dampak yang optimal.

Apabila kita merujuk pada kompetensi dasar motorik kasar anak yang diharapkan dapat distimulasi oleh guru saat anak memasuki lembaga prasekolah/taman kanak-kanak adalah anak mampu melakukan kegiatan yang berkaitan dengan keterampilan fisik motorik secara terkoordinasi dalam konteks kelenturan dan keseimbangan, ketangkasan, dan melatih keberanian. Sedini mungkin kemampuan motorik khususnya keseimbangan tubuh anak harus dioptimalkan dengan baik karena peningkatan keterampilan motorik anak akan meningkatkan kemampuan fisik, sosial emosional dan kognitif anak. Hal ini sejalan dengan pendapat (Fitri, 2017) aktivitas fisik dapat meningkatkan jumlah kapiler dalam otak, sehingga jumlah oksigen dalam otak meningkat hal ini dapat meningkatkan kinerja kognitif. Untuk itu seyogyanya kegiatan pembelajaran di sekolah tidak hanya dilakukan dengan duduk diam melainkan banyak aktifitas gerak fisik motorik untuk mengoptimalkan kerja otak dalam berfikir.

Penelitian lain menunjukkan bahwa terdapat hubungan antara keterampilan motorik dengan kesiapan sekolah anak karena kurangnya stimulasi terkait dengan keterampilan motorik (Sherry, 2013). Perkembangan fisik motorik anak akan secara langsung menentukan keterampilan anak dalam bergerak, secara tidak langsung mempengaruhi cara anak memandang dan memperlakukan dirinya serta oranglain.

Tujuan penelitian pendahuluan ini untuk menguji kelayakan paket pembelajaran permainan karpet engkle yang layak serta instrumen yang valid dan reliabel untuk digunakan dalam mengukur keseimbangan statis dan dinamis anak usia 4-5 tahun. 


\section{METODOLOGI}

Penelitian ini merupakan penelitian pendahuluan dari jenis penelitian kuantitatif deskriptif. Penelitian pendahuluan merupakan kegiatan penelitian deskriptif dan tidak digunakan untuk menguji hipotesis. Prosedur dalam penelitian ini adalah melakukan uji validasi dan uji reliabilitas pada paket pembelajaran yang akan digunakan pada penelitian. Selanjutnya, data yang telah diperoleh dianalisis secara kuantitatif dan diinterpretasikan secara deskriptif kemudian ditarik kesimpulan. Tahap-tahap penelitian diuraikan dalam bagan berikut.

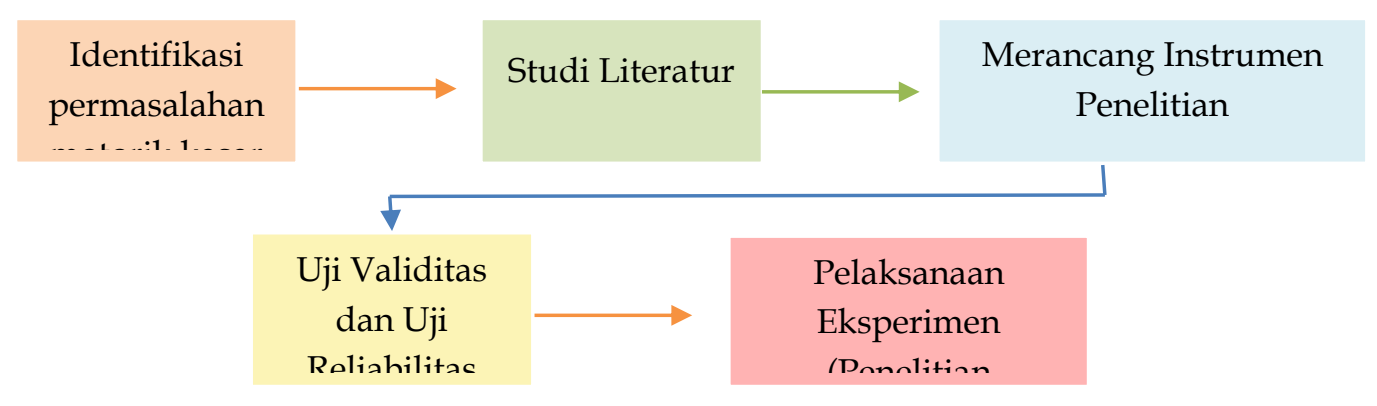

Gambar 1. Desain Penelitian

Gambar 1 merupakan ilustrasi tahap penelitian ini. Penelitian dimulai dari mengidentifikasi permasalan motorik kasar pada anak melalui observasi. Selanjutnya adalah mentelaah dan mengkaji literatur yang berkaitan dengan permasalahan. Kemudian merancang instrument penelitian, membuat kisi-kisi instrument sesuai indikator. Langkah selanjutnya melaksanakan uji validitas dan reliabilitas instrument, RPPH, perangkat pembelajaran, yang akan digunakan. Langkah terakhir adalah pelaksanaan eksperimen pada penelitian lanjutan.

Subyek penelitian akan diberlakukan pada kelompok A, anak usia 4-5 tahun dengan menggunakan teknik purposive sampling sehingga sampel dipilih atas dasar pertimbangan peneliti. Pada uji reliabilitas menggunakan satu anak sebagai subjek uji coba yang akan diamati oleh dua orang observer. Proses pelaksanaan uji reiabilitas dalam bentuk pengamatan kinerja anak, yaitu anak mempraktekkan 5 macam aktivitas motorik kasar pada aspek keseimbangan statis dan keseimbangan dinamis. Dalam menilai kinerja anak dibutuhkan pengamatan secara spesifik dan lebih efektif jika dilakukan pengamatan secara individu. Oleh karena itu satu anak sebagai subyek penelitian sudah bisa mewakili untuk mengukur konsistensi instrument yang diperoleh dari penilaian dua orang observer.

Sumber data pada penelitian ini diperoleh dari hasil uji validitas dengan teknik peer review oleh ahli (expert judgement) dan hasil uji reliabilitas dengan teknik inter-rater reliability. Uji validitas dilakukan melalui penilaian ahli dalam bentuk validitas isi (content validity) oleh ahli materi dan validitas desain yang dilakukan oleh ahli desain. Data yang diperoleh dari ahli materi dan ahli desain akan dihitung nilai rata-ratanya. Uji validitas dalam penelitian ini dimaksudkan untuk menguji instrumen kemampuan keseimbangan, rencana pelaksanaan pembelajaran harian (RPPH), alat permainan karpet engkle dan buku panduan permainan karpet engkle yang dapat digunakan dalam penelitian desain eksperimental. Validator dapat memberikan kritik dan saran untuk mengembangkan perangkat penelitian. Validasi dalam penelitian ini yakni menilai instrumen pengukuran kemampuan keseimbangan, kelayakan $\mathrm{RPPH}$, alat permainan karpet engkle, dan buku panduan penggunaan permainan.

Teknik analisis data pada uji validasi dihitung dengan mencari nilai rata-rata pada hasil penilaian validator, dengan rumus sebagai berikut.

$$
\bar{x}=\frac{\sum x}{n}
$$


Selanjutnya data kuantitatif diubah menjadi data kualitatif yang disesuaikan berdasarkan kategori pada persentase penilaian, dengan rumus sebagai berikut.

$$
\text { Presentase }=\frac{\text { skor yang diperoleh }}{\text { skor maksimal }} \times 100 \%
$$

Setelah proses validasi selesai, maka dilakukan uji reliabilitas, Uji reliabilitas dalam penelitian ini digunakan untuk mengetahui sejauh mana konsistensi instrumen kemampuan keseimbangan yang telah dibuat. Pengujian reliabilitas menggunakan teknik inter-rater reliability, diuji dengan menganalisis konsistensi butir-butir item pada instrument. Teknik analisis data uji reliabilitas menggunakan rumus Cohen`s Kappa untuk mencari tingkat koefisien kesepakatan antar rater.

\section{HASIL DAN PEMBAHASAN}

Paparan hasil penelitian diuraikan berdasarkan hasil uji validitas dan reliabilitas. Validator, dalam penelitian ini yaitu selaku dosen ahli PG PAUD yang berkompetensi dalam anak usia dini. Proses validasi dilaksanakan pada hari Jumat, 20 Juni 2020 dengan memvalidasi instrumen, $\mathrm{RPPH}$, serta paket pembelajaran (alat permainan karpet engkle dan buku panduan permainan karpet engkle) untuk mengetahui apakah layak digunakan pada penelitian eksperimen yang akan datang atau tidak layak. Hasil nilai rata-rata dan presentase uji validasi pada penelitian ini disajikan pada tabel berikut ini.

Tabel 1. Hasil Nilai Rata-Rata Validasi Ahli

\begin{tabular}{|c|c|c|}
\hline Validasi & Nilai Rata-rata & Kategori \\
\hline Instrumen & 4,5 & Sangat baik \\
\hline RPPH & 4,3 & Sangat baik \\
\hline $\begin{array}{c}\text { Alat permainan karpet } \\
\text { engkle }\end{array}$ & 4,5 & Sangat baik \\
\hline $\begin{array}{c}\text { Buku panduan } \\
\text { permainan }\end{array}$ & 4,2 & Sangat baik \\
\hline
\end{tabular}

Sumber: Data Validator

Tabel 2. Hasil Persentase Validasi Ahli

\begin{tabular}{|c|c|c|c|}
\hline Validasi & $\begin{array}{c}\text { Total } \\
\text { Skor }\end{array}$ & Persentase & Kategori \\
\hline Instrumen & 32 & $91,42 \%$ & Baik sekali \\
\hline RPPH & 43 & $86 \%$ & Baik sekali \\
\hline $\begin{array}{c}\text { Alat permainan } \\
\text { karpet engkle }\end{array}$ & 64 & $91,42 \%$ & Baik sekali \\
\hline $\begin{array}{c}\text { Buku panduan } \\
\text { permainan }\end{array}$ & 47 & $85,45 \%$ & Baik sekali \\
\hline
\end{tabular}

Sumber: Data Validator

Berdasarkan tabel 1 dan tabel 2 menunjukkan semua hasil uji validitas memperoleh nilai rata-rata diatas 4,2 dikategorikan sangat baik dan hasil persentase diatas $81 \%$ dikategorikan baik sekali. 


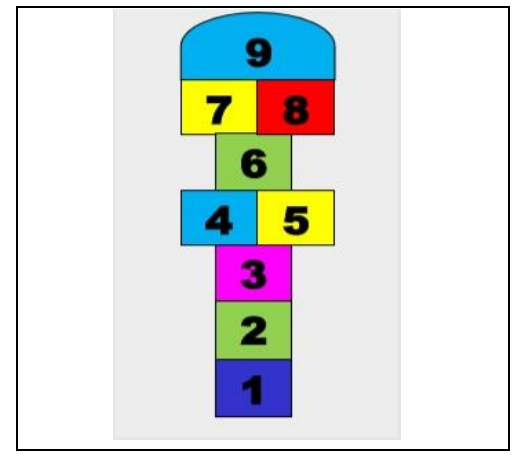

Gambar 2. Desain Karpet Engkle

Gambar 2 merupakan desain karpet engkle yang telah divalidasi dan dinyatakan valid serta layak digunakan. Desain karpet engkle dibuat menarik agar dapat menarik perhatian anak. Sesuai dengan saran validator, warna pada alas dasar permainan ini diberi warna polos. Pada tiap kotak engkle diberi warna yang kontras dengan warna dasar. Hal ini dilakukan untuk membuat anak lebih fokus pada saat bermain.

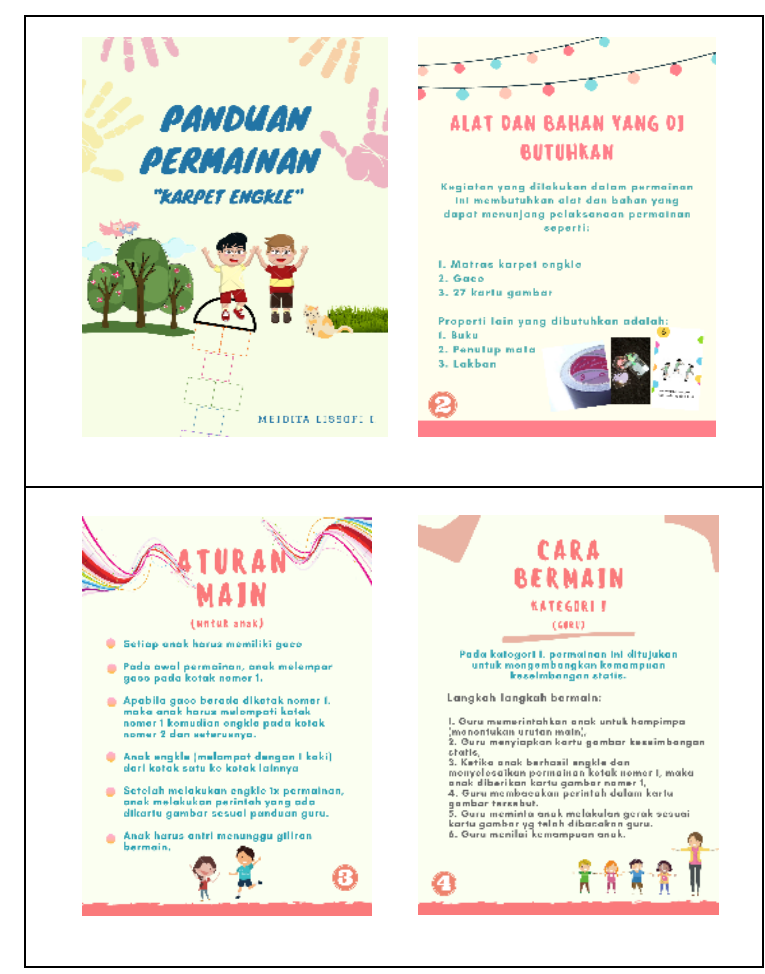

Gambar 3. Desain Bagian dalam Buku Panduan Permainan

Gambar 3 merupakan desain buku panduan yang telah divalidasi dan dinyatakan valid serta layak digunakan. Komponen dalam buku panduan ini, diantaranya: cover, aturan main secara umum, alat dan bahan yang dibutuhkan, aturan main untuk anak, cara bermain untuk guru kategori I, II, dan III, ketentuan permainan yang terbagi menjadi kategori I, II, dan III, serta panduan penggunaan kartu gambar mulai dari kategori I, II, dan III.

Pengujian reliabilitas data penelitian ini, menggunakan kesepakatan antar rater (interrater reliability). Untuk menghitung nilai kappa diperlukan tabel $2 \times 2$, yang menunjukkan jumlah atau proporsi kesepakatan yang dicapai antar rater (Widhiarso, 2010). Pengamat I dan pengamat II melaksanakan pengamatan pada Senin 29 Juni 2020, memperoleh hasil sesuai yang tertera pada tabel 3. 
Tabel 3. Data Hasil Pengamatan Uji Reliabilitas

\begin{tabular}{|c|c|c|c|c|}
\hline & & \multicolumn{2}{|c|}{ Pengamat II } & \multirow[t]{2}{*}{ Jumlah } \\
\hline & & + & - & \\
\hline \multirow[t]{2}{*}{ Pengamat I } & + & 4 & 1 & 5 \\
\hline & - & 1 & 4 & 5 \\
\hline \multicolumn{2}{|l|}{ Jumlah } & 5 & 5 & 10 \\
\hline
\end{tabular}

Berdasarkan tabel 3, pengamat I memperoleh kesepakatan sebanyak 4, tidak sepakat 1, dan pengamat II memperoleh kesepakatan 4 dan tidak sepakat 1 dari 5 butir-butir instrument yang telah dinilai. Antara pengamat 1 dengan pengamat II memiliki tingkat kesepakatan yang sama, maka koefisien reliabilitas yang dihasilkan akan tinggi. Selanjutnya data tersebut dimasukkan ke dalam rumus Cappa Kohen dan memperoleh hasil 0.75, sehingga dapat dikategorikan koefisien kesepakatan kuat. Artinya instumen yang dibuat bersifat reliabel.

\section{Analisis Validasi}

Penelitian ini mengangkat point of view keseimbangan tubuh, karena kemampuan keseimbangan sangat penting bagi pengoptimalan kemampuan anak lainnya. Hal ini didukung oleh pendapat (Susanti 2010; Irfan, 2010) memiliki kemampuan menyeimbangkan massa tubuh yang baik akan membuat keterampilan gerak dan melakukan berbagai aktivitas menjadi lebih efektif dan efisien.

Balance exercise atau latihan keseimbangan tepat digunakan untuk mengatasi masalah gangguan keseimbangan. Kegiatan balance exercise di sekolah salah satunya dapat dilakukan melalui olahraga dan permainan. Didukung oleh penelitian (Lasmaida, 2016) dibutuhkan media sebagai sarana bermain untuk merangsang perkembangan motorik dalam melatih keseimbangan tubuh pada saat berpindah tempat dibawah pengawasan guru. Penelitian ini menggunakan permainan karpet engkle sebagai media untuk melatih gerakan motorik kasar khususnya keseimbangan statis dan dinamis, memacu penggunaan otot besar anak, mengontrol gerakan tubuh, koordinasi, serta meningkatkan keterampilan tubuh, sehingga dapat menunjang pertumbuhan jasmani yang kuat, sehat dan terampil. Didukung oleh pendapat (Luh dkk., 2018) permainan engkle sangat bermanfaat bagi anak karena mengkoordinasikan gerak kaki dan tangan anak untuk menjaga keseimbangan tubuhnya pada saat membawa benda pada telapak tangan, belajar melatih kesabaran pada saat membawa benda, memperkuat otot-otot anak, meningkatkan kepercayaan diri anak ketika melompat, melatih konsentrasi anak pada saat melompat. Pendapat ini didukung penelitian sebelumnya oleh Wiranti \& Mawarti (2018), menjelaskan bahwa melalui permainan engkle anak lebih mudah melakukan gerakan motorik kasar, merasa senang pada saat pembelajaran dan bermain secara berkelompok.

Permainan karpet engkle adalah permainan modifikasi dari permainan tradisional engkle. Tujuan utama memodif permainan adalah untuk membuat permainan menjadi lebih menarik untuk anak, sehingga pada proses pembelajaran dapat memberikan dampak yang optimal karena anak merasa senang mengikuti jalannya permainan. Hal ini sesuai dengan hasil penelitian yang dilakukan oleh Munawaroh (2017), bahwa pengembangan model pembelajaran dengan permainan tradisional engkle dilakukan dengan bermain sambil belajar, bersifat inovatif, aktif, kreatif dan menyenangkan menjadi salah satu model pembelajaran yang dapat menstimulasi dan mengekplorasi 6 aspek perkembangan anak. Sejalan dengan hal tersebut pada penelitian (Astutik \& Fitri, 2019), dengan mengubah permainan tradisional menjadi permainan lola kena bertujuan untuk mendukung perkembangan kognitif anak karena dapat melatih anak untuk menjaga keseimbangan, mengkoordinasikan gerakan dan kelenturan, serta memperhatikan karakteristik anak membuat keterampilan motorik anak usia 5-6 tahun meningkat. 
Langkah-langkah bermain karpet engkle sesuai gambar 1 pada desain karpet engkle, adalah: (1) anak melempar gaco ke kotak nomor 1, kemudian berjalan engkle (satu kaki) ke kotak nomer 2 sampai nomer 9; (2) kemudian berbalik, berjalan engkle, dan mengambil gaco pada kotak nomer 1; (3) selanjutnya anak mengambil kartu gambar dan dberikan kepada guru; (4) guru membacakan isi kartu gambar dan memerintahkan anak untuk melakukan kegiatan sesuai isi dalam kartu gambar; (5) langkah terakhir, anak mengikuti perintah guru, dan melempar gaco pada kotak nomer 2, begitu seterusnya.

Permainan karpet engkle telah diuji oleh validator sebanyak 3 butir item aspek penilaian dengan 14 indikator. Hasil penilaian validator mengenai alat permainan karpet engkle didapatkan skor rata-rata 4,5, dengan nilai presentase $91,42 \%$. Sesuai dengan kriteria penilaian maka alat permainan karpet engkle dikategorikan baik sekali sehingga valid dan layak digunakan. Adapun kesimpulan dari validator adalah alat permainan karpet engkle ini LD (layak digunakan).

Permainan karpet engkle memiliki panduan permainan yang didesain berupa media cetak ukuran A5. Buku panduan permainan karpet engkle berfungsi membantu guru dalam menerapkan permainan karpet engkle pada pembelajaran disekolah. Buku panduan sangatlah penting untuk digunakan guru sebagai bahan ajar pembelajaran khususnya dalam kegiatan bemain (Kurniawan, 2019). Sejalan dengan pendapat dari Andi (2015) yang mengatakan bahwa fungsi buku panduan sendiri merupakan alat bantu untuk pendidik dimana di dalam pelaksaannya terdapat kurikulum untuk bahan referensi, sebagai telaah dari teknik dan metode pengajaran yang digunakan oleh pendidik. Hal ini didukung oleh penelitian (Sulistyaningtyas, dkk., 2019) melalui buku panduan permainan tradisional, proses pembelajaran guru dalam meningkatkan kemampuan motorik kasar anak menjadi lebih optimal, sehingga kemampuan anak juga meningkat.

Komponen dalam buku panduan permainan karpet engkle, diantaranya: cover, aturan main secara umum, alat dan bahan yang dibutuhkan, aturan main untuk anak, cara bermain untuk guru kategori I, II, dan III, ketentuan permainan yang terbagi menjadi kategori I, II, dan III, serta panduan penggunaan kartu gambar mulai dari kategori I, II, dan III. Buku panduan permainan karpet engkle dilengkapi dengan gambar untuk memudahkan guru. Pendapat ini didukung oleh penelitian Aulya (2019) dalam buku panduan, instruksi permainan dilengkapi dengan gambar pendukung untuk memudahkan instruktur atau guru dalam memahami langkah-langkah permainan yang harus diikuti. Alat dan bahan juga disajikan dalam bentuk gambar beserta keterangannya. Buku panduan dikatakan baik apabila telah disesuaikan dengan tujuan atau media pembelajaran. Penggunaan buku panduan akan sangat berguna untuk mempermudah dan memahami kegiatan pembelajaran atau menggunakan media pembelajaran sesuai dengan tujuannya (Nasrulloh \& Reza, 2020)

Buku panduan permainan karpet engkle telah diuji sebanyak 3 butir item aspek penilaian dengan 11 indikator. Hasil penilaian validator mengenai buku panduan permainan memiliki skor rata-rata 4,2, dengan presentase $85,45 \%$. Sesuai dengan kriteria penilaian maka dikategorikan baik sekali sehingga layak digunakan. Adapun data kesimpulan dan saran dari validator untuk modul panduan permainan karpet engkle ini adalah LD (layak digunakan). Buku panduan telah direvisi berdasarkan saran dari validator yaitu memperbaiki urutan tata letak aturan bermain dengan langkah-langkah bermain yang bertujuan untuk perbaikan agar tepat guna. Sejalan dengan penelitian Masitha (2020) dengan melakukan revisi berdasarkan saran dan komentar dari validator dalam pemakaiannya, buku banduan menjadi lebih efisien, efektif dan mudah digunakan untuk para pembaca.

Selanjutnya, lembar instrumen observasi berbasis perilaku pada penelitian ini akan digunakan untuk mengukur kemampuan keseimbangan statis dan dinamis dalam penelitian selanjutnya. Instrumen dimaksudkan untuk menghasilkan data riil yang akurat. Sejalan dengan pendapat Daryanto (2011) instrumen penelitian digunakan sebagai alat pengumpul data yang memiliki peran sangat penting dalam proses penelitian. Didukung oleh pendapat 
Masyud (2012) menyatakan melalui instrument, semua data dalam penelitian dapat diperoleh secara akurat dan tidak ada yang terlewat.

Uji validasi instrumen dilakukan untuk menilai lembar observasi berbasis perilaku serta menunjukkan keabsahan dari instrumen yang akan digunakan dalam mengukur kemampuan keseimbangan anak usia 4-5 tahun valid atau tidak. Sejalan dengan penelitian Retnawati (2016) , proses uji validasi digunakan untuk melihat kesesuaian indikator dengan tujuan pengembangan instrumen, kecakupan materi/kesesuaian teori, melihat kebenaran isi, dan menilai bahasa yang digunakan.

Instumen yang dikembangkan dalam penelitian ini memuat 5 indikator, diantaranya 3 indikator keseimbangan statis (anak mampu melakukan gerak statis dengan posisi berdiri) dan 2 indikator keseimbangan dinamis (anak mampu melakukan gerak dinamis dengan berjalan). Indikator telah disesuaikan dengan capaian perkembangan anak sesuai usianya.

Instrumen penelitian ini telah diuji sebanyak 7 butir item aspek penilaian instrumen dengan indikatornya. Hasil penilaian validator mengenai instrument penelitian didapatkan skor rata-rata 4,5 dengan presentase $91,42 \%$. Berdasarkan hasil tersebut sesuai dengan kriteria penilaian maka instumen dikategorikan baik sekali sehingga valid dan layak digunakan. Kesimpulan dari validator adalah instrument kemampuan keseimbangan anak LPD (layak digunakan dengan perbaikan) dengan saran pada instrumen penilaian dibagian kanan sediakan kolom untuk skala penilaian (rating scale 1-4, dengan angka 4 didahulukan terakhir angka 1). Instrumen pengukuran kemampuan keseimbangan anak kelompok A usia 4-5 tahun yang telah diuji dan dapat digunakan untuk penelitian desain eksperimen, dituangkan dalam tabel 4.

Tabel 4 Instrumen Pengukuran Kemampuan Keseimbangan Anak Usia 4-5 Tahun

\begin{tabular}{|c|c|c|c|}
\hline No & Aspek & Indikator & Butir Item \\
\hline \multirow[t]{3}{*}{1} & Keseimbangan Statis & $\begin{array}{l}\text { Anak mampu malakukan } \\
\text { gerak statis dengan posisi } \\
\text { berdiri }\end{array}$ & $\begin{array}{l}\text { Anak mampu berdiri dengan } \\
\text { satu kaki (kaki kanan diangkat) } \\
\text { selama } 10 \text { detik. }\end{array}$ \\
\hline & & & $\begin{array}{l}\text { Anak mampu berdiri dengan } \\
\text { satu kaki (kaki kiri di angkat) } \\
\text { selama } 10 \text { detik. }\end{array}$ \\
\hline & & & $\begin{array}{l}\text { Anak mampu berdiri diatas } \\
\text { kursi setinggi } 15 \mathrm{~cm} .\end{array}$ \\
\hline \multirow[t]{2}{*}{2} & $\begin{array}{l}\text { Keseimbangan } \\
\text { Dinamis }\end{array}$ & $\begin{array}{l}\text { Anak mampu melakukan } \\
\text { gerak dinamis dengan } \\
\text { berjalan. }\end{array}$ & $\begin{array}{l}\text { Anak mampu melakukan gerak } \\
\text { dinamis dengan berjalan. }\end{array}$ \\
\hline & & & $\begin{array}{l}\text { Anak berjalan tandem satu kaki } \\
\text { ditempatkan di depan kaki lain } \\
\text { dengan tumit kaki depan } \\
\text { menyetuh jemari kaki belakang. }\end{array}$ \\
\hline
\end{tabular}

Selanjutnya, rencana pelaksanaan pembelajaran harian pada penelitian ini berfungsi sebagai panduan pelaksanaan treatment yang telah disesuaikan dengan skema treatmen 1 sampai 3 yang telah dirancang sebelumnya agar pelaksanaan treatmen (pembelajaran) dapat berjalan secara efektif. RPPH berpengaruh besar bagi kesuksesan suatu kegiatan treatment. Sejalan dengan pendapat Zamzami (2017), RPPH dirancang dengan membuat skenario pembelajaran dan indikator aspek perkembangan yang dipilih agar sesuai dengan tema dan subtema. Sejalan dengan pendapat Gol (2019), RPPH merupakan perencanaan program harian yang dilaksanakan oleh pendidik atau pengasuh setiap hari sesuai dengan program institusi. $\mathrm{RPPH}$ digunakan sebagai tolak ukur bagi pendidik dalam mengembangkan kreatifitas materi dan kreatifitas saat pembelajaran (Fitri, dkk., 2017).

Rencana pelaksanaan pembelajaran harian (RPPH) harus disusun secara rinci. RPPH memiliki indikator penting, antara lain: identitas program, tujuan pembelajaran, materi pembelajaran, sumber belajar, alat dan bahan yang digunakan, kegiatan awal, kegiatan inti 
dan kegiatan penutup pembelajaran. RPPH dalam penelitian ini memuat kompetensi dasar, muatan materi, tujuan pembelajaran, media, metode, dan penilaian. Apabila RPPH yang telah dibuat tidak lengkap, hal ini membuat performance guru dalam mengajar menjadi berkurang (Sufiati, 2019). Didukung oleh Makruf (2015) bahwa RPPH yang disusun secara baik menjamin setengah dari kegiatan pembelajaran telah berhasil diselesaikan. RPPH yang tersusun secara terstruktur akan membantu pelaksana pembelajaran (guru) dalam melaksanakan tugasnya mendidik dan mengajar menjadi lebih baik.

Uji validitas RPPH dilakukan untuk menilai rencana pembelajaran yang akan dilakukan pada saat melaksanakan prosedur treatmen. RPPH telah diuji oleh validator sebanyak 10 butir item aspek penilaian dengan indikatornya. Hasil dari uji validitas RPPH mendapatkan skor rata-rata 4,3, dengan nilai presentase $86 \%$. Sesuai dengan kriteria penilaian maka RPPH dikategorikan baik sekali dan layak digunakan. Adapun kesimpulan dan saran dari validator untuk RPPH yang dikembangkan adalah LPD (layak digunakan dengan perbaikan). Saran validator pada bagian langkah kegiatan tetap menggunakan pembagian dengan menuliskan sub judul kegiatan pendahuluan, kegiatan inti, kegiatan penutup. Isi kegiatan penutup sesuaikan dengan aspek RPPH nomer 8.

\section{Analisis Reliabilitas}

Uji reliabilitas dalam penelitian ini melibatkan dua rater atau ahli (inter-rater reliability) dengan melihat serta menguji tingkat kesepakatan (agreement) antar rater dalam menilai setiap indikator pada instrument. Inter-rater reliability akan memberikan gambaran tentang tingkat kesepakatan yang diberikan ahli atau rater dalam bentuk skor.

Jika instrumen memberikan hasil yang konstan atau konsisten, maka instrumen tersebut dikatakan reliabel. Didukung oleh pendapat (Sugiyono, 2013), instrumen yang reliabel adalah instrumen yang menghasilkan data yang sama ketika digunakan untuk mengukur obyek yang sama berulang kali. Apabila item pernyataan pada instrument sudah valid dan reliable maka item pernyataan tersebut dapat digunakan untuk pengumpulan data.

Tahap reliabilitas dalam penelitian ini dilakukan dengan cara memberikan lembar instrument pengamatan kemampuan keseimbangan kepada rater/pengamat yang didalamnya memuat 5 indikator dari aspek keseimbangan statis dan keseimbangan dinamis untuk digunakan mengamati subjek dengan teknik rating scale/menggunakan ceklist. Data yang dihasilkan adalah data ordinal berupa nilai $4=\mathrm{BSB}, 3=\mathrm{BSH}, 2=\mathrm{MB}$, dan $1=\mathrm{BB}$. Pada saat uji reliabilitas, rater menilai kemampuan keseimbangan anak. Anak di minta melakukan aktifitas sesuai pernyataan dalam instrumen, dan pengamat dapat memberikan penilaian dengan standart yang sama dan hasilnya objektif.

Penelitian ini menggunakan koefisien kesepakatan Cohen Kappa karena melibatkan dua rater atau pengamat untuk menghitung reliabilitas antar 2 rater. Penggunakan koefisien kappa digunakan apabila rater yang dipakai tidak banyak, satu subjek dinilai oleh dua rater, skor hasil bersifat kategori (Widhiarso, 2010). Berdasarkan perhitungan menggunakan rumus Cohen Kappa, memperoleh hasil sebesar 0.75, diinterpretasikan kesepakatan kuat. Hal tersebut sesuai dengan kesepakatan koefisien cut value dimana 0,79 lebih kecil dari 0,80 dan lebih besar dari 0,60. Artinya instrumen kemampuan keseimbangan anak usia 4-5 tahun bersifat reliabel, dan dapat digunakan dalam penelitian. Setelah instrumen bersifat reliabel, itu artinya instrumen dapat dipergunakan untuk menilai suatu objek.

\section{SIMPULAN}

Berdasarkan hasil penelitian dan pembahasan disimpulkan bahwa hasil dari uji validitas dan uji reliabilitas instrumen, RPPH dan paket pembelajaran (alat permainan karpet engkle dan buku panduan) dinyatakan valid dan reliabel serta dapat digunakan untuk mengukur kemampuan keseimbangan anak usia 4-5 tahun. Penelitian ini memberi sumbangan ide dan gagasan, paket pembelajaran yang praktis digunakan guru khususnya dalam melatih keseimbangan tubuh anak. Dengan adanya hasil preliminary research ini 
diharapkan dapat dilanjukan dalam desain penelitian selanjutnya yaitu penelitian eksperimen dengan rancangan penelitian menggunakan quasi exsperimental design, jenis non equivalent control grup design untuk melihat pengaruh dari permainan karpet engkle pada anak usia 4-5 tahun di Taman Kanak-kanak.

\section{UCAPAN TERIMAKASIH}

Ucapan terimakasih kepada pihak-pihak yang terkait dalam proses penelitian ini yang telah membantu dan melancarkan jalannya penelitian serta penyusunan artikel ilmiah ini.

\section{DAFTAR PUSTAKA}

Adhe, Kartika et al. 2018. “The Implementation of Physical Fitness Learning Module in Kindergarten." In , 156-58.

Afiyah, Aulya Fitriyani Sa'ul, and Sigit Purnama. 2019. "Pengembangan Buku Panduan Outboundkids Kelompok Usia 5-6 Tahun." Golden Age Jurnal Ilmiah Tumbuh Kembang Anak Usia Dini 4(1): 11-12.

Astutik Fera Setia Puji. Fitri, Ruqoyyah. 2019. “Pengaruh Permainan 'Lola Kena' Terhadap Kemampuan Motorik Kasar Anak Usia 5-6 Tahun Di TK Aisyiyah Bustanul Athfal 25 Wage Sidoarjo." PAUD Teratai 8(2): 1-6.

Daryanto. 2011. Penelitian Tindakan Kelas Dan Penelitian Tindaka Sekolah Besrta ContohContohnya. Yogyakarta: Gava Media.

Erlinda, E, IW Dharmayana, and N Syam. 2014. "Pengembangan Motorik Kasar Anak Usia Dini Melalui Permainan Melempar Dan Menangkap Bola." http:/ / repository.unib.ac.id/8663/.

Fitri, Annisa. 2017. "Perencanaan Pembelajaran Kurikulum 2013 Pendidikan Anak Usia Dini (Penelitian Deskriptif Kuantitatif Di Paud IT Auladuna Kota Bengkulu)." Jurnal Ilmiah POTENSIA 2(1): 1-13.

Fitri, Ruqoyyah. 2017. "Metakognitif Pada Proses Belajar Anak Dalam Kajian Neurosains." Jurnal Pendidikan (Teori dan Praktik) 2(1): 56.

Gaol, Ramsa Lumban. 2019. "Peningkatan Kompetensi Guru Dalam Menyusunrencana Program Pembelajaran Harian ( Rpph ) Melalui Peran Pengawas Sekolah." jurnal Tematik 9(2): 39-45.

Irfan, M., and J. Susanti. 2008. "Pengaruh Penerapan Motor Learning Programme (MRP) Terhadap Peningkatan Keseimbangan Berdiri Pada Pasien Stroke Hemiplegi." Jurnal Fisioterapi Indonusa 8(2): 109-26. https:/ / ejurnal.esaunggul.ac.id/index.php/Fisio/article/view/612.

Irfan, Muhammad. 2010. Fisioterapi Bagi Insan Stroke. 1st ed. Jakarta: Graha Ilmu.

Kurniawan, Arufendra. 2019. "Pengembangan Buku Panduan Bermain Dan Alat Permainan Berbasis Scientific Approach Untuk Anak Usia 5-6 Tahun." http:/ / repository.unsri.ac.id/id/eprint/ 2484.

Lasmaida, Riska. 2016. Meningkatkan Keseimbangan Dinamis Melalui Berjalan Di Atas Garis Lurus Di TK ABA Krajan Yogyakarta.

Luh Ayuning Sundari, Ni Ketut Suarni, Putu Aditya Antara. 2018. "Penerapan Permainan Tradisional Dengkleng Dengan Metode Demonstrasi Untuk Meningkatkan Keseimbangan Tubuh Anak Kelompok A Singaraja." Journal Pendidikan Anak Usia Dini Undiksha 6(1): 126-35.

Makruf., Imam. 2015. Modul 7 Guru Kelas Raudhatul Athfal. Pengembangan Perangkat Pembelajaran Untuk RA. Jakarta: UIN Syarif Hidayatullah.

Munawaroh, Hidayatu. 2017. “Pengembangan Model Pembelajaran Dengan 
Permainan Tradisional Engklek Sebagai Sarana Stimulasi Perkembangan Anak Usia Dini." Jurnal Obsesi: Jurnal Pendidikan Anak Usia Dini 1(2): 86. http://stacks.iop.org/1347-4065/48/024501.

Nasrullah, Ayu Cahya, and Muhammad Reza. 2020. “Pengembangan Buku Panduan Kegiatan Pembelajaran Mitigasi Bencana Kebakaran Pada Anak Usia 5-6 Tahun." PAUD Teratai 1-12. https://jurnalmahasiswa.unesa.ac.id/index.php/paudteratai/article/view/34329.

Permana, Fajar Widya Dhias. 2013. “Perkembangan Keseimbangan Pada Anak Usia 7 s/d 12 Tahun Ditinjau Dari Jenis Kelamin." Jurnal Media Ilmu Keolahragaan Indonesia 3(1).

Prastowo, Andi. 2015. “Panduan Kreatif Membuat Bahan Ajar Inovatif: Menciptakan Metode Pembelajaran Yang Menarik Dan Menyenangkan." DIVA Press: 1-373. Retnawati, Heri. 2016. Analisis Kuantitatif Instrumen Penelitian (Panduan Peneliti, Mahasiswa, Dan Psikometrian). Pertama. Yogyakarta: Parama Publishing.

Rindang, Wredha, and Asih Ungaran. 2014. “Efek Pemberian Latihan Keseimbangan Dalam Mempertahankan Kemampuan Keseimbangan Manula Panti Wredha Rindang Asih 1 Ungaran." Journal of Sport Sciences and Fitness 3(1): 49-54.

Schwam, Zachary G., and George Wanna. 2019. "Pediatric Vestibular Disorders." In Diagnosis and Treatment of Vestibular Disorders, , 353-61.

Sufiati, Vivi, and Sofia Nur Afifah. 2019. "Peran Perencanaan Pembelajaran Untuk Performance Mengajar Guru Pendidikan Anak Usia Dini." Jurnal Pendidikan Anak 8(1): 48-53.

Sugiyono. 2013. Metode Penelitian Kuantitatif, Kualitatif Dan RED. Bandung: Alfabeta. Sulistyaningtyas, Reza Edwin, and Puji Yanti Fauziah. 2019. "Pengembangan Buku Panduan Permainan Tradisional Untuk Meningkatkan Kemampuan Motorik Kasar Anak Usia 5-6 Tahun." JPPM (Jurnal Pendidikan dan Pemberdayaan Masyarakat) 6(1): 50-58.

Sulthon Masyud. 2012. Metode Penelitian Pendidikan. Jember: Lembaga Pengembangan Manajemen dan Profesi Kependidikan.

Widhiarso, Wahyu. 2010. 2 Perbedaan Pengertian Aspek Dan Dimensi Dalam Pengembangan Alat Ukur. http://widhiarso.staff.ugm.ac.id/files/widhiarso_2010_perbedaan_pengertian_aspek_dan_dimensi_dalam_pengembangan_alat_ukur .pdf.

Wiranti, Dwiana Asih, and Diah Ayu Mawarti. 2018. "Keefektiffan Permainan Engklek Dalam Mengembangkan Kemampuan Motorik Kasar Anak Usia Dini." Refleksi Edukatika: Jurnal Ilmiah Kependidikan 9(1).

Wiyani, Novan Ardy. 2014. Psikologi Perkembangan Anak Usia Dini, Panduan Bagi Orang Tua Dan Pendidik PAUD Dalam Memahami Serta Mendidik Anak Usia Dini. Yogyakarta: Gava Media.

Yossy Wirda Utami, Desni Yuniarni, Lukmanulhakim. 2017. "Analisis Tingkat Pemahaman Guru Terhadap Kegiatan Pembelajaran Pada Taman Kanak-Kanak Di Kota Pontianak." Jurnal Pendidikan dan Pembelajaran Untan 6(7). 